\title{
Characteristics of teachers' support on learning: a case study
}

\author{
Anna Sardà1,2, Conxita Márquez ${ }^{2}$, and Neus Sanmartí2 \\ ${ }^{1}$ Educational Institution: Fundació Privada Collsersola, Escola Avenç, Barcelona, Catalonia, Spain \\ 2,* Department of Science and Mathematics Education, University Autonoma of Barcelona, Bellaterra, Barcelona, Catalonia, \\ Spain \\ For correspondence: anna.avenc@gmail.com
}

\begin{abstract}
:
One of the problems in science education research is obtaining evidence that particular teacher support of learning helps achieve better academic results for students. Classroom ecology involves many variables that are difficult to control and, moreover, many results can only be seen in the medium term. The purpose of this case study on an expert science teacher is to identify the main variables that characterise the teachers' suport on learning and to obtain evidence that really helps to improve the students' scientific literacy. The scientific literacy level of students has been assessed by some 2000 and 2003 PISA items. The findings show that explicit teaching by metacognitive strategies and the implementation of communication skills, accompanied by a warm, firm caring atmosphere in class, is a powerful educational tool to improves students' learning, particularly students with low to medium academic achievements.
\end{abstract}

Keywords: teacher's support on learning, scientific literacy, metacognitive strategies, communication skills, classroom atmosphere, PISA evaluation.

\section{Introduction}

One purpose of science teaching research is to provide information on teaching and learning practices that improve science learning. However, although research continues to increase and the number of publications, conferences and researchers also increases, it often has little impact on educational policies and practices (Staver 2005).

One hypothesis to explain this fact is the difficulty in providing evidence that innovatory teaching practices based on research make a real improvement to academic results (Leach 2007; Jagger and Yore 2012; Capps and Crawford 2012). In addition, studies are usually carried out in the short term following teaching experiences in a limited space of time which make it impossible to draw any conclusions on more long-term learning. As noted by Fraser (1980) and Aldridge, Fraser, Bell and Dorman (2012), research into relationships between science teacher characteristics and student outcomes denies the complexity of naturalistic classroom settings.

Another problem is finding systems that assess significant learning in science that are widely recognised in order to reach a conclusion on whether certain educational practices improve results. In this regard, we believe that the PISA questionnaires designed by international scientific education experts to assess the scientific literacy of fifteen year-old students (OECD 1999-2010) can be used as a benchmark for this purpose. There is also a broad consensus as to their quality compared with other types of assessment and that the right answer to the questions they pose requires a degree of education on the part of the students that cannot be achieved in a single activity

Lastly, another problem is identifying the variables that characterise the innovations applied and which explain the results obtained. Although research may be designed to assess the appropriateness of some of the possible variables, from the perspective of classroom ecology it is difficult to separate them from the many other variables involved.

For example, the results will be better if teachers are convinced of the worth of the innovation applied. Other factors with an influence include the teachers' training and their experience in 
applying any of the features of the innovation, the characteristics of the class groups involved and the atmosphere generated in the classroom.

We agree that what a teacher does during the teaching process has an impact on students' learning (McKeachie 2007) but there is no denying that the one doing the learning is the student and, therefore, the study focuses on classifying what the teacher does to make the students actively committed to their learning (Biggs 1999; Chickering and Gamson 1987; Mc Dowell et al. 2010).

Although it is difficult to conclude that one particular aspect of science teaching practice has a greater influence than another on students' learning results, the question posed by this research is whether it is possible to identify the main variables that characterise a teacher's practices which have been classified as good by other colleagues and which lead to students obtaining good results when responding to the PISA programme questions, as explained in the following section (see table 1, group J).

\section{Research context and objective}

This research was performed within the context of an educational institution made up of three schools with a total of 4000 pupils. The Science Teaching Department of this institution decided to ascertain what results their fifteen to sixteen year-old students would obtain in an evaluation using questions from the PISA programme, in the area of science.

A questionnaire was designed using four questions of the free test items from PISA 2000 and 2003, because 2006 PISA items were not yet available (the research began in 2005). The criteria used to select questions were as follows:

- The students had to be able to complete the test in one hour (the usual time given to students to carry out diagnostic/internal assessment tests at the institution concerned).

- They covered the fundamental aspects of the scientific competency definition.

- Work had to have been done on the scientific content over the last four secondary school years.

- The content involved the four science areas of the secondary school: Biology, Geology, Physics and Chemistry.

- There were different kinds of questions: explanations, long and short questions, drawing conclusions from a database, graphics, etc....

The selected questions are as follows: Peter Cairney and Semmelweis (PISA, 2003), Ozone and Buses (PISA, 2000). These questions are made up of 2-4 items each so that they enable the three scientific competencies proposed by the PISA programme to be assessed (Competency A - Prediction, explanation and prediction of scientific phenomena; Competency B - Identification of scientific issues; Competency C - Interpretation of evidence to draw conclusions), they are formulated as multiplechoice or open constructed response questions and require a low, medium or high level of reasoning from the students.

Once the assessment had been designed, a pilot questionnaire with two students was applied. The intention was to verify whether they had time to answer the four questions in one hour and whether they encountered any particular difficulties in understanding the questions correctly, as students were not familiar with the PISA questions or the format of the test. After the questionnaire, the students were interviewed briefly to ascertain their impressions. It was concluded that the questionnaire could be done with the students of the ten classes.

To assess the level of scientific literacy achieved by the students when answering the questionnaire, the criteria of the Programmes for International Student Assessment (PISA) 2000 and 2003 were applied. The students' responses were graded into three levels of skill or competency, with level 1 being associated with the full development of the individual and level 3 with having resources and strategies to deal with competitiveness and future development. 
To grade the questionnaire each teacher was given a protocol with the assessment criteria and examples of valid and invalid responses published by PISA 2000 and 2003. Each teacher marked a number of tests that had been exchanged randomly among the teachers. Using the same criteria, an external evaluator, not involved in the research, marked a sample chosen at random of three questionnaires per class group. The external evaluator's marks coincided in $90 \%$ of cases with the other marks.

The questionnaire was applied to all the tenth grade students at the institution (10 class groups). The results of one of the classes (table 1) was better than the rest of the class groups. The group (group J) that obtained the best results, due to organisational reasons at the institution, exceptionally had had the same teacher for four years (from 7th to 10th grade). The group was assigned this teacher at random and consisted of 22 students. The other class groups had had the same teacher only in 7th and 8th grade and another teacher in 9th and 10th. Since all of these teachers were from the same institution they all followed the same curriculum. They also gave all the students the same exams that they prepared together.

Table 1. Results of the ten groups according to competence level (PISA 2000 and 2003), L1 is the lowest competence level.

\begin{tabular}{|c|c|c|c|}
\hline & L1 & L2 & L3 \\
\hline Group A & 53.3 & 40.0 & 6.7 \\
\hline Group B & 50.0 & 46.4 & 3.6 \\
\hline Group C & 56.7 & 40.0 & 3.3 \\
\hline Group D & 72.4 & 27.6 & 0.0 \\
\hline Group E & 67.9 & 32.1 & 0.0 \\
\hline Group F & 36.0 & 48.0 & 16.0 \\
\hline Group G & 35.7 & 57.1 & 7.2 \\
\hline Group H & 32.1 & 57.1 & 10.8 \\
\hline Group I & 24.0 & 68.0 & 8.0 \\
\hline Group J & 9.09 & 72.73 & 18.18 \\
\hline
\end{tabular}

The first group described in the preceding paragraph (group J), with $n=22$ students, is called the Experimental Group as it obtains better results according to PISA programme parameters. In the experimental group, most of the students are at a medium level (L2) of competence, there are very few students at level 1 and the percentage of students at a high level (L3) is twice the percentage of those at a low level.

The other groups obtained results that were worse overall since almost all of the students can be divided equally into the two bottom competence levels and only a few are at the highest level. Therefore, these groups were included in the so-called control group throughout the research.

An analysis of these results could lead to the conclusion that the explanation for the difference is that the experimental group is academically better than the control group. However, as shown in table 2, the average grade (of a total of 10 points) of the students during the school year (in all disciplines) in the experimental group was 5.52, whereas the average grade of the control group was 6.39. The experimental group is the group of the teacher being studied in this research. The teacher had been teaching this group science for four school years and, therefore, the results can be explained basically as a result of her teaching methods.

Table 2. Results of the experimental group and the control group according to competence level (PISA 2000 and 2003), (the Chi-Square Test; significance level of 0.05)

\begin{tabular}{|c|c|c|c|c|}
\hline \multicolumn{2}{|c|}{ Experimental Group } & & \multicolumn{2}{|c|}{ Control Group } \\
\hline & $\%$ & \multirow{4}{*}{$\mathrm{p}=0,0006$} & & $\%$ \\
\hline L1 & 9.09 & & $\mathbf{L 1}$ & 45.0 \\
\hline $\mathbf{L 2}$ & 72.73 & & $\mathbf{L 2}$ & 46.3 \\
\hline L3 & 18.18 & & L3 & 6.2 \\
\hline
\end{tabular}




\begin{tabular}{ccccc}
\hline $\mathrm{n}=22$ & 100 & $\mathrm{n}=248$ & 100 \\
\hline & 5.52 & & average grade & 6.39 \\
\hline
\end{tabular}

Based on these results, we decided to carry out a case study to identify the main variables that characterise the practice of the teacher in the group achieving better results.

\section{Research methodology}

We set forth below the teacher's professional profile, although the aim of this study is not so much to explain what makes her a good teacher, but rather to identify the dominant aspects concerned and how they affect student learning.

The teacher whose practice is characterised in this case study, the first signatory of this article, has seven years' experience, a degree in primary school education and another in biology. She has a master's in science education, specialising in the teaching of argumentation in science class. She has also published various types of innovative curricular material and participated in several projects. From the start of her professional career, she has formed part of a science teaching research group linked to the university where the study was performed.

In order to identify the variables characteristing the teacher's practice a panel of experts was created, made up of two qualified teachers. These teachers hold doctorates in science teaching and have considerable experience of leading projects and research work. They also know the institution and the teacher because they have worked together on various educational projects. Based on an analysis of the activities applied in the classroom, the students' productions and observation of some classes, the experts proposed the variables of the teacher's practice which they considered could be classified as excellent and, lastly, they agreed upon these variables with her.

These aspects of teacher practice were cross-referenced against the students' viewpoints. Two focus groups were used for this purpose, each comprising five students, who had formed part of the teacher's class group for four years (from seventh to tenth grade). One of the group comprised students who were continuing with studies relating to science or technology (ST) and the other group was made up of students who were studying social sciences or humanities (SH). The interview was carried out when these students had finished their secondary school studies (at the end of twelfth grade, two years after they had had the teacher).The participants were chosen so that there were students with diverse academic results. Each group contained one student of a high academic level, one of a low academic level and three students of intermediate levels. They were sent an e-mail briefly explaining the objectives of the study and were asked to participate in the focus group.

The expert teachers proposed the variables to be studied and asked an external person who did not know the teacher or the students to pose the following four blocks of questions to the students:

- the class methodology used by the teacher

- personal teaching style and personality

- application/usefulness of what they had learned for later studies

- each student's personal experience

The questions followed a pre-established script although, obviously, new questions were introduced if the students' answers so required. The discussion groups were recorded and analysed based on the variables identified by experts as relevant in the teacher's practice. This article includes examples taken from the discussions that illustrate the students' opinions.

\section{Data collection and analysis}

The type of data collected for analysis is shown in table 3: ideas transcribed during the interviews of the two focus groups, the analysis of the written productions of some students and the field work reports of the two experts who observed some classes. The analysis of the data served as the basis for 
identifying the variables that characterised the practical knowledge of the teacher in this case study. The data provided evidence of the recognition by the students of the variables proposed by the expert teachers. Lastly, they were agreed upon with the teacher under study.

Table 3. Type of data collected for the analysis of the teaching practice

\begin{tabular}{c|c}
\hline \multicolumn{1}{c}{$\begin{array}{c}\text { Data Collection } \\
\text { focus groups } \\
\text { forviews of the two }\end{array}$} & recordings and transcripts of a length of one hour with each focus group \\
\hline $\begin{array}{c}\text { written productions } \\
\text { of some students }\end{array}$ & $\begin{array}{c}\text { dossiers of the students, exams, class activities and laboratory experiments } \\
\text { relating to the four school years (from 7 th to 10 th grade) }\end{array}$ \\
\hline $\begin{array}{c}\text { field work reports } \\
\text { (FWR) of the two } \\
\text { experts }\end{array}$ & $\begin{array}{c}\text { each expert visited the teacher once a month in the first six months of the school } \\
\text { year following the obtainment of the results of the application of the PISA } \\
\text { questionnaire. The field work observations were coded as follows: A or B: expert } \\
\text { teacher A or B, numbers 1 to 6: day of the observation. }\end{array}$ \\
\hline
\end{tabular}

\section{Results and analysis}

After this process, the three variables which it was agreed best characterised the teacher's teaching practice were as follows.

Capacity to develop students' communicative competence

One of the variables that best characterises the teacher's activity is her concern with using science classes to improve students' communicative competence, in other words, improve the way they speak and write about science. She spends a lot of time (FWR-A2, FWR-B3) teaching them to describe, explain, justify, argue or define in the language of science (Lemke 1990; Sutton 1992; Author 3 1997; Yore and Treagust 2006; Osborne 2010), bearing in mind that her objective is for her students to be capable of explaining events around them scientifically.

According to Norris and Phillips (2003) the capacity to construct and interpret science texts is fundamental to demonstrating science literacy, and therefore depends on students developing both procedural and conceptual knowledge entailed in scientific representation. Learning this disciplinary literacy, as noted by Moje (2008), means learning not just subject knowledge but also the multiple ways of "knowing, doing, believing and communicating" in this subject.

The teacher therefore spends time encouraging her students to consider the rules for constructing the various types of text (FWR-A2, FWR-B3) when science is communicated, and ensuring that they are clear on the criteria required for assessing quality, in terms of content and form. She believes that each linguistic genre needs to be acquired by students and explicitly taught through suitable instruction, task structuring, and modelling in an integrated manner as part of the teaching of scientifc concepts.

The students also recalled that the teacher insisted that they should explain and argue their ideas. Following are some of the sentences from the focus groups:

"She said that more than learning or memorising things, it is important that you know how to reason, explain and above all understand them and, of course, give arguments to support your ideas" (ST -science or technology-).

For example, she uses Toulmin's Argument Pattern (TAP) (Toulmin 1958) not just to analyse how her students construct an argument but so that they are able to self-regulate (Author 1 and Author 3, 2000). In other words, the students know TAP, and know that their arguments must include the various components (data, claim, warrant, rebuttal and backings), they have to use various types of connectors and they must be coherent. They also have patterns to construct a description or a definition that they have learned as required for the various learning activities (FWR-A4). 
These patterns are not ready-made but are constructed step by step, in the same way as science ideas do not come pre-prepared or packaged (Sutton 1992). The teacher suggests activities to the students that encourage them to explain, first in their own words, the phenomena they observe in experiments or that are provided to them for scientific study (Aufschnaiter et al. 2007; Simon et. al. 2006 ) (FWRB4). They discuss the relationships between the observations made in experiments with the theoretical models. They read about theories that have been both rejected and accepted by the scientific community and the teacher encourages the students to explain the reasons for their decisions, the evidence, as well as the interests and values that could be behind a discovery or contribution (FWR-B4).

The students were aware of the teacher's insistence on constructing arguments (FWR-A4):

"We always had to explain something, argue based on what we had done or said in class or some premise. Also in the exams, for example, we had to explain something or other ... or argue what we thought about what three people said, who you thought was right" ( $\mathrm{SH}$-social sciences or humanities).

Special emphasis is given in the classes to drafting the conclusions of the experiments, so that they answer "good" questions and are well argued, taking into account the evidence obtained and the theoretic frameworks discussed (FWR-B4). She thinks that because the students need to explain they should have queries and ask themselves questions, according to Harlen (2004) and Roca, et al (in press). She discussed with her students how to know if a question is "good", based on considering if it can be solved, it is obvious, arbitrary or ambiguous..., since according to Chin and Osborne (2010), helping students to ask themselves this type of question -based on key ideas- in an interactive environment helps them to organise and improve their arguments (FWR-A3). She tries to ensure that the question does not limit the students to "saying" the answer, but ensures that they observe, think and act to "construct" the answer (Amos, 2002). For example, some students also highlighted this characteristic of the teacher:

"What she did a lot was to make us think a lot. I mean, she didn't give you the answer, You asked a question and she made you think of the answer yourself. She made you find the answer" (SH).

Capacity to encourage students' self-regulation using metacognition

With the experience she has acquired, the teacher is convinced of the importance of encouraging students to self-regulate their learning metacognitively, i.e. to develop their capacity to identify the causes of difficulties and errors and take decisions to overcome them, while interacting with others (Authors 1995; Black 1998; White and Frederiksen 2000). She thinks that teaching students to construct scientific explanations of events means teaching them to think in a theoretical way, i.e. to find coherence between their own representations and the facts and ways of representing and communicating them based on self-regulating thinking, action and language in an interrelated manner (Guidoni 1985; Izquierdo and Adúriz 2003). This means being able to identify and analyse possible inconsistencies which arise in the course of the learning process and take decisions to selfregulate them to be able to understand life situations involving science and act responsibly and critically (Millar 2006).

Normally, the task of self-regulation falls to the teacher who analyses the students' productions, analyses the errors and suggests ways for the students to correct them. However, the teacher tries to make the students themselves undertake the process as part of training assessment (Nunziati 1990; Author 3 2007) and become aware of what they know and what they do not know, plan their own activities, use time effectively, predict the successful outcome of their own efforts, control the effectiveness of the action or verify the result of an attempt to resolve a problem (Baumert et al. 2000).

She applies very varied strategies, always trying to ensure that the students understand the assessment to be regulation. In the classes, it was observed (FWR-B2, FWR-A6) that although the aim was to make the activity systematic and for the objectives to be similar, the types of actions encouraged were not repetitive. She encourages the students to reflect on issues individually, in pairs 
or in small groups and in relation to any type of production, whether it be practical work, reading or exams. At first, the students thought that the emphasis on meta-reflection was one of the teacher's "obsessions" and they were only interested in the grades they received; but gradually they started to realise how it helped them, above all, to ask for advice effectively. The students with the most difficulties found it the hardest to self-regulate but they improved by analysing reflections by other students or by constructing a guide for the questions to ask to think about whether they were wrong or incoherent, what the mistake was and why it was made.

The students said:

"Yes, yes ... you had to think about what you had done wrong, what you hadn't understood, try to think why you had made a mistake ... and give arguments. Sometimes you didn't feel like doing it but I suppose it was a good thing" (ST).

"Yes... and at the end of the lab practice, when we did the conclusions, she made us think and write "what have I learned?", what haven't I understood? Did I like it?..." (SH).

It was seen that in the classroom they worked on both cognitive and metacognitive aspects, especially those that enabled the students to be autonomous when it came to guiding their self-regulating work (FWR-B2, FWR-A6). The teacher tried to make them regulate their representation of the objectives (Schunk 1996) and, accordingly, she started the teaching sequences with activities aimed at representing and sharing them (FWR-A1). And, every now and then, throughout the sequence she encouraged them to identify what had been achieved and what still had to be learned (FWR-B3). She also emphasised the assessment criteria to ensure that the students knew them and could recognise whether they were doing the work correctly and what they needed to ask for help with (FWR-A6).

Another aspect she spent time on was ensuring that the students were capable of planning their actions (FWR-B3), whether they were general actions, such as making a guide to solve problems, designing a hypothetical/deductive experiment or, as mentioned, arguing. Or in relation to specific contents, such as how to think about applying the living being model to identify whether someone is alive or the kinetic/mollecular model to interpret physical changes in materials. She encouraged them to create their "Orientation Base" (Nunziati 1990), outlines, summaries or other strategies that involved considering separately any operations and ideas to be taken into account when thinking, acting and communicating, and regulating them so that, although they might be provisional, there were no errors. Very often, this type of planning was used to deduct the assessment criteria applied by the students to evaluate their productions.

This method of working is consistent with studies performed in the fields of self-assessment and metacognition (Zimmerman 1990; Pintrich and De Groot, 1990; Boekaerts, 1999; Perrenoud 1998), and their application in science education (White and Gustone 1999, White and Frederiksen, 1998; Zohar 2004; Ben-David and Zohar 2009).

From the analysis of the students' productions, it could be seen that this type of learning requires time. Some students do it "spontaneously" but for the majority, this approach requires a fundamental change in the way they study and also in their attitudes and emotions. Therefore, it is difficult to ascertain results in the short term.

For example, at first when the students performed a written self-assessment they only used expressions such as: I didn't know how to explain it properly, I got confused, I hadn't studied it, I didn't know, I didn't understand the formulation properly (L.A. 12 years old). A month later, the same student, who had learning difficulties, was more specific and did not just focus only on herself, but also on the contents of the task: I got confused because I said that milk with cocoa is a chemical change instead of a physical change because, in theory, when we mix the two substances, it looks like we change their properties, but it's also true that if we let the cocoa rest it forms a sediment without changing. In tenth grade (at 15 years old) she had learned to define quite well the errors she had made and even analyse the language she used to express herself: Because I associated the concept of force with the concept of movement I considered that some of the sentences in the formulation were correct 
when they weren't. For example, even if you bang a table with force, if the table doesn't move it is not correct to use the concept of force.

The first reflections made by this student are not at all constructive because she is not able to identify the errors and, even less, think why she made them. However, gradually, she starts to recognise and pinpoint errors relating to the contents of the learning. In fact, as also seen by White and Fredericksen (1998), it was with the students who had the lowest performance that the effects of helping them develop their metacognitive and self-regulating capacity could be noted the most, certainly because the most successful had learnt to do it independently.

Often students do not easily recognise their mistakes and learn to do so particularly when they analyse classmates' productions in mutual assessment activites. Students exchange their productions and have to help their classmates to improve them, normally by applying the assessment criteria agreed upon and this is when they most recognise their own mistakes, in line with the work of Authors (1996) and Black et al. (2004).

Part of this work was done in small groups in which ideas and working methods were discussed (FWR-B3). Discussion is fostered by a context in which student-student interaction is permitted and encouraged (Jiménez-Aleixandre et al. 2000; Zohar and Nemet 2002). The teacher tried to get her students to recognise, on the one hand, that a variety of points of view is good and makes it possible to access not a singular world-view but plural accounts of phenomena and the evidence that can be deployed in an argument (Osborne et al. 2004). And on the other hand, that discussion should focus on the ideas which are what is being assessed/regulated and not the people.

Also in this context of small work groups the students learn to value the importance of improving their communicative competence. They see that they do not understand what a classmate has written and that ideas must be expressed well so that others can understand them. Teachers can infer what students want to say in a piece of written work but their classmates cannot. The teacher encouraged students to become aware of this fact.

Lastly, when it came to evaluating the students' work and giving marks she tried to be as transparent as possible and justify the reasons for the marks she gave. The students remembered this well and said:

"She explained why she had lowered your mark. Normally, teachers just give you a mark and don't explain it and you ask "let's see, why is that?". She didn't; she put each point, you did that well for this reason, for that reason ...." (ST).

\section{Confidence in the students' learning abilities}

A third variable in which the teacher particularly stands out relates to her teaching style which she has developed over the years, based mainly on creating an atmosphere in the classroom that "blend(s) warmth and firmness towards the students, but with realistic limits" (Jones and Jones 2010). She is actually demanding and more demanding than warm, does not give up on any of her students learning and we think that this characteristic explains to a large extent that the number of her students that obtain bad results in competence-type tests is low.

It is well known that teachers' pedagogical practice is strongly influenced by their expectations of students' success (Kuntera et al. 2011). With students who are not considered to have high cognitive capacities, teachers tend to set learning activities with a low level of conceptual and abstract content and are generally less demanding. Basically, the students are asked to repeat definitions or explanations learned practically by heart and this is justified by saying that these students cannot be expected to do any more.

This is not the case with the teacher under consideration but just the opposite in fact. She constantly encourages these students to go beyond simple mechanical explanations (FWR-B1, FWR-A5). She encourages them time and time again to reflect metacognitively on the quality of their work and take 
decisions on how to improve it, step by step (Smart and Marshall 2012). In this respect she considers that mutual assessment activities are very useful because when the students with the most difficulties read classmates' productions and their recommendations they can see more easily where they can make progress, rather than if the teacher tells them directly. At the same time, the more advantaged students also recognise which aspects they could improve, even though the partner assessing their work may not have identified them. Students remembered this aspect in the interview:

"I liked it that she took everything as a challenge, to say I'm going to bring this up for discussion whatever it takes and always with the best intentions. She had ways of working with enthusiasm so that everyone could understand, from those who found it the hardest to those who found it the easiest and more or less everyone ended up enjoying it. Including people who liked the subject and those that didn't" (SH).

She manages to get her students not to give up because she creates an atmosphere in the classroom that fosters science learning. She manages this not by trying to conduct fun classes but more by sharing the objectives with her students and transmitting her enthusiasm for science and teaching (FWR-B4, FWR-A1). For example, some students said:

"You could see that she really enjoyed giving the class. This motivated you because she enjoyed it a lot, you know, you could tell that she really liked what she was explaining to you" (SH).

She achieves all this because she is thorough and demands a great deal. She does not accept halffinished work or badly argued work and she does not let herself be convinced by the students who, as is to be expected, tend to try and make her give in on this point (FWR-B6). At the beginning, they find her too demanding and are even disconcerted by the type and level of work she requires but, finally, most become aware that they have been helped to learn science in a more meaningful way (Peters, 2010).

"More than difficult, I think, it was her method, because it was very thorough. She was very on top of things. She was very consistent" (ST).

As Schunk (2003) notes, "perceived students' self-efficacy or personal beliefs about their capabilities to learn or perform behaviors, plays an important role in their motivation and learning. Self-efficacy affects choice of tasks, effort, persistence, and achievement. At the outset of learning activities, students have goals and a sense of self-efficacy for attaining them. Self-evaluations of learning progress sustain self-efficacy and motivation".

There is a consensus (Zimmerman and Martinez-Pons 1990; Boekaerts 1999) that cognitive and motivational aspects are equally important in self-regulation: "Students can be described as selfregulated to the degree that they are metacognitively, motivationally, and behaviorally active participants in their own learning process" (Zimmerman 1989). Pintrich and De Groot (1990) defined metacognition as "the will and the skill" and "the will" was clearly one of this teacher's objectives, as the students described:

"She gave you a lot of confidence even though she was strict, for example, there are teachers who if they have to give you a 10, just give you a 10 and that's it, but she gave you a 10 and she congratulated you..." (ST).

In short, based on the interviews, the students in the focus groups demonstrated that the teacher was thorough, organised and constant and was consistent when it came to what she proposed and what she required. At the time they were experiencing it, the students did not value this demanding teaching method but most of them recognised that in the long term she had helped them to develop these skills themselves. The students also acknowledged that the teacher respected and understood the students and showed interest in the large majority of them reaching the objectives that had been set. Although sometimes the students recognised that she could make things quite heavy-going: 
"It was quite tiring having to always justify things, even the most simple things ... and I thought: "I have to tell you why though it seems obvious?" And you even had to explain why. Sometimes, you'd done it so many times that you ended up saying: "I'm tired, do you know what I mean?" (SH).

\section{Discussion}

This article focuses on research that analyses teaching practice to obtain evidence that particular teacher support of learning helps students to achieve better academic results.

Regarding the relationship between the variables identified and their effect on the obtainment of good results by the experimental group, it has been shown that a significant aspect was the work done on developing communication skills in sciences. The PISA questions mostly require the preparation of justifications and arguments using the concepts learned to explain facts and phenomena, conclusions to be drawn from experimental evidence and information to be questioned in a critical manner.The second aspect is that the results of the experimental group can also be explained by the self-regulation work done by the students which they put into practice by answering the PISA questions because they do not involve memorisation but require students to think about the connection between the facts shown and the theoretical explanation given

Lastly, the third aspect that also explains the good results achieved by the students in the experimental group was that, as they were accustomed to doing, they did not give up looking for a suitable answer to the questions put to them. They also felt able to carry out the various tasks and use all their knowledge in a variety of areas.

A second conclusion that can be drawn in relation to these three variables identified and analysed in the teacher's practice -the capacity to develop communicative competence, encouraging selfregulation using metacognition and confidence in the students' learning abilities- is that they were were significant mainly for two reasons:

Firstly, because the result is a teaching practice which is rich in interaction between students and the teacher and between the students themselves (Scott et al. 2006). In order to learn, it is necessary to discuss ideas and observations and, to do this, the teacher stressed that students should help each other. The teacher also worked to ensure that all of the students learned, and she was convinced that they could do so, in an atmosphere of trust.

Secondly, this teaching practice enables students to develop their own learning tools to be able to learn about science throughout their lives. This aspect was demonstrated, on the one hand, in the development of the students' capacity for self-regulation using metacognition, a capacity highlighted by various authors such as Boekarts, et al. (2005) and White and Frederiksen (1998). And on the other hand, in the development of communicative competence which involves an effort by the students to speak and write in the language of science (Pearsonet al. 2010).

It can be seen that the teacher's characteristics that were identified contribute to increasing the students' active role in their learning. This is because they are able to acquire self-regulation techniques in a positive learning environment. In fact, self-regulation is a strategy that enables students to become more committed to their own learning process as they need to develop an active and conscious role (Zimmerman, 1989; Zimmerman, 2000; Pintrich, 2000).

From the data collected by the two experts it can be deduced that three variables of the teacher's work are totally integrated into her classroom practice to encourage students' learning. They are not just sporadic activities undertaken every now and again but are used from the start of each teaching/learning sequence. From a student-centred/learning-oriented viewpoint of the classroom work (Kember 1997; Simmons et al. 1999, Granger et al. 2012), for example, the teacher started with an activity to gather information on the students' thoughts, analyse and discuss it with them, looking for points of contact and making the effort to understand what could help them. 
The activities she designed were aimed at connecting what the students learned with socially relevant problems, particularly those relating to the environment, to stimulate their capacity to form opinions and decide and act accordingly (Kolsto 2001). This approach is clearly related to scientific literacy (Prain and Waldrip 2010). In addition to those already noted, special mention should be made of the way in which she planned the experimental work, focusing on looking for evidence, asking good research questions, etc...

These characteristics are desirable in a class where what is really important is what the students do and how they learn. Even though, as stated in the article, the same teacher applied the same strategies over four school years, a conclusion cannot be reached on the time required for the effects to be seen in an improvement of results. What is certain, however, is that it is not important to have the same teacher, but what counts is the degree to which teachers use these variables. What does not work is for teachers to perform an activity every now and then which works on communication or selfregulation in isolation. Having the same teacher for four years may not be the most appropriate for students because they do not see other ways of doing things, but this did occur in our study for logistical reasons, as explained.

Another notable aspect of this research which raises questions is that a large proportion of the students in the experimental group obtained good results in the scientific competence assessment but did not obtain such good results when faced with more traditional tests as shown in the average grade. This information can be deducted from the fact that the average grade in the experimental group was lower than in the control group but, on the other hand, the results concerning scientific competence were better in level 2 and in level 3 (see table 2). It should be noted that the ten groups at the three schools underwent similar tests, agreed upon by the teachers and that, until the school year in which this study was performed, these tests had basically been tests of memory and reproducing facts. A possible explanation is that the two types of test assess very different knowledge and that competence-based learning requires different teaching methods to traditional approaches. It is also possible that a large number of the students cannot find any purpose to the scientific knowledge they are usually expected to acquire but are more interested in learning that connects with subjects from their experience.

In this research we have focused on these characteristics which, because they are applied competently and coherently, and we believe explain the good results obtained. However, we have not focused on other characteristics we also observed which we consider could be improved upon. For example, although the teacher has good science teaching training in biology, the same cannot be said of the contents relating to chemistry and physics that she has to teach. The experimental work she proposes and her use of information and communication technologies could also be improved considerably. However, this was not an obstacle to her students achieving scientific competence.

Lastly, it was interesting to have data on the students two years after they had finished tenth grade. These students, of diffent types and levels of learning, identified the various aspects making up the three variables anlaysed, were aware of having worked intensively on them, and were able to recognise the teaching aim of each. Although they found it disconcerting at first and during the process it was quite laborious to carry out in the end most were convinced that it had helped them in their science learning. As the students said:

"It wasn't that it was hard, we went from studying the definition of plants and the parts of a flower, to asking: what does it mean that it is a flower? (SH)"

"She made it difficult for me but when you had found out how to do it and got a good mark, then you were happy and satisfied" (ST)

\section{Acknowledgements}

Based on work supported by MCYT grant EDU2012-38022-CO2-O2 and catalan PRI-2009SGR1543. The authors thanks the teachers and students involved in the research. 


\section{References}

Aldridge, J.M.; Fraser, B.J.; Bell, L. \& Doman, J. (2012). Using a New Learning Environment Questionnaire for Reflection in Teacher Action Research. Journal of Science Teacher Education, 23(3), 259-290.

Amos, S., Gould, G., \& Watts, M. (2002). The role of pupil's questions in learning science. In A. Amos, S., \& Booham, R. (Eds). Aspects of teaching secondary science (pp. 39-48), London: The Open University.

Aufschnaiter, C. v., Erduran, S., Osborne, J. \& Simon S. (2007). Arguing to learn and learning to argue: Case studies of how students' argumentation relates to their scientific knowledge. Journal of Research in Science Teaching, 45 (1), 101-131.

Baumert, J., E. Klieme, M. Neubrand, M. Prenzel, U. Schiefele, W. Schneider, K., J. Tillmann, \&M. Weib. (2000). Self-regulated learning as a cross-curricular competence. Berlin: Max-Planck Institut fur Bildungsforschung.

Ben-David, A. \& Zohar, A. (2009). Contribution of Meta-strategic Knowledge to Scientific Inquiry Learning. International Journal of Science Education, 31 (12), 1657-1682.

Biggs, J. (1999). What the student does: teaching enhanced learning. Higher Education Research \& Development, 18 (1), 57-75.

Black, P. (1998). Formative assessment: raising standards inside the classroom. School Science Review, 80 (291), 39-46.

Black, P., Wiliam, D., Lee, C. \& Harrison, C. (2004). Teachers developing assessment for learning: impact on student achievement. Assessment in Education, 11 (1), 49-65.

Boekaerts, M. (1999). Self-regulated learning: where we are today. International Journal of Educational Research, 31, 445-457.

Boekaerts, M., Pintrich, P.R., \& Zeidner, M. (2005). Handbook of self- regulation. San Diego: Academic Press.

Capps, D.K. \& Crawford, B.A. (2012). Inquiry-Based Instruction and Teaching About Nature of Science: Are They Happening? Journal of Science Teacher Education, August 2012 .Chickering, A., \& Gamson, Z. (1987). Seven principles of good practice in undergraduate education. AAHE Bulletin, 39, 3-7.

Chin,C., \& Osborne, J. (2010). Students' questions and discursive interaction: Their impact on argumentation during collaborative group discussions in science. Journal of Research in Science Teaching, 47 (7), 883-908.

Cochran-Smith, M., \& Lytle, S. L. (1999). Relationships of Knowledge and Practice: Teacher Learning in Communities. Review of Research in Education, 24 (1), 249-305.

Domingos, A.M. (1989). Conceptual Demand of Science Courses and Social Class. In: Adey, P. et al. (eds). Adolescent development and school science. London: The Falmer Press.

Driel, J. H. v., Beijaard, D., \& Verloop, N. (2001). Professional Development and Reform in Science Education: The Role of Teachers' Practical Knowledge. Journal Of Research In Science Teaching, 38 (2), 137-158.

Fraser B. J. (1980). Science Teacher Characteristics and Student Attitudinal Outcomes. School Science and Mathematics, 80 (4), 300-308.

Granger, E. M., Bevis, T. H., Saka, Y., Southerland, S. A., Sampson, V., \& Tate, R. L. (2012). The Efficacy of Student-Centered Instruction in Supporting Science Learning. Science, 338, 105-109

Guidoni, P. (1985). On natural thinking. European Journal of Science Education, 7 (2), 133-140.

Harlen, W. (2004). Teaching, learning and assessing science 5-12. 3rd edn. London: Paul Chapman Publishing.

Izquierdo, M., \& Adúriz, A. (2003). Epistemological Foundations of School Science. Science \& Education, 12, 27- 43.

Jagger, S.L. \& Yore, L.D. (2012). Mind the Gap: Looking for Evidence-Based Practice of Science Literacy for All in Science Teaching Journals. Journal of Science Teacher Education, 23 (6), 559-577. Jimenez-Aleixandre, M., Rodríguez, A., \& Duschl, R. (2000). Doing the lesson "or" doing science: Argument in high school genetics. Science Education, 84 (6), 757-792.

Jones, V. F., \& Jones, L. (2010). Responsible Classroom Discipline: creating positive learning environments and solving problems. Boston: Allyn and Bacon.

Kember, D. (1997). A reconceptualisation of the research into university academics conceptions of teaching. Learning and Instruction 7 (3), 255-275.

Kolsto, S. D. (2001). “To trust or not to trust,..." students' ways of dealing with a socioscientific issue. International Journal of Science Education, 23 (9), 877-901.

Kuntera, M.; Frenzelb, A.; Nagyc, G.; Baumert, J. \& Pekrune, R. (2011). Cover image Teacher enthusiasm: Dimensionality and context specificity. Contemporary Educational Psychology, 36 (4), 289-301.

Leach, J. (2007). Contested territory: The actual and potential impact of research on teaching and learning science on students' learning. In: R. Pintó and D. Couso (eds), Contributions from Science Education Research. Dordrecht: Springer.

Lemke, J. L. (1990). Talking science: Language, learning, and values. Norwood, NJ: Ablex.

McDowell, L., Wakelin, D., Montgomery, C., \& King, S. (2010). Does assessment for learning make a difference? The development of a questionnaire to explore the student response. Assessment and Evaluation in Higher Education, First published on: 23 June 2010 (iFirst), 1-18.

McKeachie, W.J. (2007) Good Teaching Makes a Difference-And we Know What It Is. The Scholarship of Teaching and Learning in Higher Education: An Evidence-Based Perspective. ( pp 457-474).

Millar, R. (2006). Twenty First Century Science: Insights from the design and implementation of a scientific literacy approach in school science. International Journal of Science Education, 28 (13), 1499-1521.

Moje, E. (2008). Foregrounding the disciplines in secondary literacy teaching and learning: A call for change. Journal of Adolescent and Adult Literacy, 52 (2), 96-107.

Norris, S. P., \& Phillips, L. M. (2003). How literacy in its fundamental sense is central to scientific literacy. Science Education, 87 (2), 224-240.

Nunziati, G. (1990). Pour construire un dispositifd'evaluation formatrice. Cahiers pédagogiques, 280, 47-64.

OECD (1999). Measuring Student Knowledgw and Skills -A New Framework for Assessment. Paris : OECD.

OECD (2000). Measuring student knowledge and skills - The PISA 2000 Assessment of Reading. Mathematical and Scientific Literacy, Paris: OECD.

OECD (2003). The PISA 2003 Assessment Framework: Mathematics, Reading, Science and Problem Solving. París: OCDE.

OECD (2007). PISA 2006 Science Competences for tomorrow's world. Paris : OECD.

OECD (2010). PISA 2009 Results: Executive Summary. Paris : OECD.

Osborne, J. (2010). Arguing to Learn in Science: The Role of Collaborative, Critical Discourse. Science, 328, 463-466. 
Osborne, J., Erduran, S., \& Simon, S. (2004). Enhancing the quality of argumentation in school science. Journal of Research in Science Teaching, 41 (10), 994-1020

Pearson, P.D., Moje, E., \& Greenleaf, C. (2010). Literacy and Science : Each in the service of the other. Science, 328, 459-463.

Perrenoud, P. (1998). From Formative Evaluation to a Controlled Regulation of Learning Processes. Towards a wider conceptual field. Assessment in Education: Principles, Policy \& Practice, 5 (1), 85-102.

Peters, E.E. (2010). Shifting to a Student-Centered Science Classroom: An Exploration of Teacher and Student Changes in Perceptions and Practices. Journal of Science Teacher Education, 21 (3), 329-349.

Pintrich, P. R., \& De Groot, E. V. (1990). Motivational and self-regulated learning components of classroom academic performance. Journal of Educational Psychology, 82 (1), 33-40.

Prain, V., \& Waldrip, B. (2010). Representing science literacies: An introduction. Research in Science Education, 40 (1), 1-3.

Roca, M.; Márquez, C. \& Sanmartí, N. (2013). Las preguntas de los alumnos: Una propuesta de analisis. Enseñanza de las ciencias. 31 (1) 95-114.

Sadler, T. D., \& Zeidler, D. L. (2009). Scientific literacy, PISA, and socioscientific discourse: Assessment for progressive aims of science education. Journal of Research in Science Teaching, 46 (8), 909-921.

Sanmartí, N. ( 2007). 10 ideas clave. Evaluar para aprender. Barcelona: Graó.

Sanmartí, N. (1997). Para aprender ciencias hace falta aprender a hablar sobre las experiencias y sobre las ideas. Textos de didáctica de la lengua y de la literatura, 8, 27-40.

Sardà, A. \& Sanmartí, N. (2000). Enseñar a argumentar científicamente: Un reto de las clases de ciencias. Enseñanza de las ciencias, 18 (3), 405-422.

Sardà, A.; Márquez, C. \& Sanmartí, N. (1995). Autorregulación de los procesos de aprendizaje y construcción de conocimientos. Alambique, 4, 59-77.

Sardà, A.; Márquez, C. \& Sanmartí, N. (1996). Enseñar, aprender y evaluar: un proceso de regulación continua. Propuestas didácticas para las áreas de ciencias de la naturaleza y matemáticas. Madrid: MEC.

Schunk, D. (1996). Goal and self-evaluative influences during children's cognitive skill learning. American Educational Research Journal, 33 (2), 359-382.

Schunk, D. H. (2003). Self-efficacy for reading and writing: influence of modeling, goal setting, and self-evaluation. Reading $\mathcal{E}$ Writing Quarterly, 19 (2), 159-172.

Scott, P. H., Mortimer, E. F., \& Aguiar, O. G. (2006). The tension between authoritative and dialogic discourse: A fundamental characteristic of meaning making interactions in high school science lessons. Science Education, 90 (4), 605-631.

Simmons et al., (1999). Begininng teachers: beliefs and classrooms actions. Journal of reserach in Science Teaching, 36, $930-954$.

Simon, S., Erduran, S. \& Osborne, J. (2006), Learning to Teach Argumentation: Research and development in the science classroom. International Journal of Science Education, 28 (2-3), 235-260.

Smart, J.B. \& Marshall, J.C (2012). Interactions Between Classroom Discourse, Teacher Questioning, and Student Cognitive Engagement in Middle School Science. Journal of Science Teacher Education, June 2012.

Staver, J. R. (2005). Let's change before it's too late. A speech given at the awards banquet of the Annual Meeting of NARST, Dallas, TX, Retrived from http://www.educ.sfu.ca/narstsite/news/e-narstnews7-12-05.pdf.

Sutton, C. (1992). Words, Science and Learning. Buckingham: Open University Press.

Toulmin, S. (1958). The uses of argument. Cambridge: Cambridge University Press.

White, B., \& Frederiksen, J. (1998). Inquiry, modeling, and metacognition: Making science accessible to all students. Cognition and Instruction, 16 (1), 3-117.

White, B., \& Frederiksen, J. (2000). Metacognitive facilitation: An approach to making scientific inquiry accessible to all. In A Minstrell, J. \& Zee, E. van (Eds.), Inquiringin to Inquiry Learning and Teaching in Science. Washington, DC: American Association for the Advancement of Science, (pp. 331-370).

White, R.T., \& Gustone. R.F. (1998). Metalearning and Conceptual Change. International Journal Science Education. 11, 577-587.

Yore, L.D., \& Treagust, D.F. (2006). Current Realities and Future Possibilities: Language and science literacy-empowering research and informing instruction. International Journal of Science Teaching, 28, 291-314.

Zimmerman, B .J. (1990). Self-Regulated Learning and Academic Achievement: An Overview. Educational Psychologist, 25 (1), 3 17.

Zimmerman, B. J. (1989). A social cognitive view of self-regulated academic learning. Journal of Educational Psychology, 81, 329339.

Zimmerman, B.J., \& Martinez-Pons, M. (1990). Student differences in self-regulated learnng. Journal of Educational Psychology, 80, 284-290.

Zohar, A. (2004). Higher order thinking in science classrooms: student's learning and teacher's professional development. Dordrecht: Springer.

Zohar, A. \& Nemet, F. (2002). Fostering students' knowledge and argumentation skills through dilemmas in human genetics. Journal of Research in Science Teaching, 39, 35-62.

Zohar, A., \& Peled, B. (2008) The effects of explicit teaching of metastrategic knowledge on low and high achieving students, Learning and Instruction, 18, 337-353. 